\title{
UJI SENSITIVITAS BERBAGAI JENIS ANTIBIOTIK TERHADAP Salmonella $S p$. YANG DIISOLASI DARI PENDERITA DEMAM TYPHOID
}

\author{
Sensitivity Test Of Various Types Of Antibiotics To Salmonella Sp. That Is Isolated \\ From Typhoid Fever Sufferers
}

\author{
Artati $^{1}$, Zulfian Armah ${ }^{2}$, Aan Yulianingsih Anwar ${ }^{3}$ \\ ${ }^{1,2}$ Jurusan Teknologi Laboratorium Medis, Poltekkes Kemenkes Makassar \\ ${ }^{3}$ Jurusan Teknologi Laboratorium Medis, Poltekkes Kemenkes Ternate
}

Koresponden : artati@poltekkes-mks.ac.id

\begin{abstract}
Enteric Fever (Typhoid Fever) syndrome is only caused by a few types of salmonella, the most important of which is Salmonella Typhi (typhoid fever). Salmonella that is ingested will reach the small intestine, from the small intestine Salmonella enters the lymphatic tract and then enters the bloodstream. Antimicrobial therapy for invasive Salmonella infection is with ampicillin, trimethoprim-sulfamethoxazole, or third-generation cephalosporins. Resistance to various drugs transmitted genetically via plasmids among enteric bacteria is a problem in Salmonella infection. The research objective was to determine the sensitivity of several antibiotics used in sufferers of typhoid fever. Isolation method using Bact / Alert and identification of bacteria and sensitivity test using vitek 2 compact. The results showed a sensitivity test for salmonella sp for sensitive antibiotics amoxicillin and ceftriaxone, ciprofloxacin intermediate, sensitive trimethoprim.
\end{abstract}

Keywords : salmonella typhi; typhoid fever; sensitivity test

\begin{abstract}
ABSTRAK
Demam Enterik (demam Typhoid) sindrom ini hanya ditimbulkan oleh beberapa jenis salmonella, yang terpenting adalah Salmonella Typhi (demam typhoid). Salmonella yang tertelan akan menscapai usus halus, dari usus halus Salmonella memasuki saluran limfatik dan kemudian masuk ke aliran darah. Terapi antimikroba untuk infeksi Salmonella invasif adalah dengan ampisilin, trimethoprim-sulfametoksazol, atau sefalosporin generasi ketiga. Resistensi terhadap terhadap berbagai obat yang di transmisikan secara genetik melalui plasmid diantara bakteri enterik merupakan masalah pada infeksi Salmonella. Tujuan penelitian untuk mengetahui sensitivitas beberapa antibiotik yang digunakan pada penderita demam typhoid. Metode isolasi menggunakan Bact/Alert dan identifikasi bakteri serta uji sensitivitas menggunakan vitek 2 compact. Hasil penelitian menunjukkan uji sensitifitas terhadap salmonella sp untuk antibiotik amoxicillin dan ceftriaxone sensitif, ciprofloxacin intermediate, trimethoprim sensitif.

Kata kunci: salmonella typhi, demam typhoid, uji sensitivitas
\end{abstract}




\section{PENDAHULUAN}

Demam enterik (Demam Typhoid) sindrom ini hanya ditimbulkan oleh beberapa jenis salmonella, yang terpenting adalah Salmonella Typhi (demam typhoid). Salmonella yang tertelan akan mencapai usus halus, dari usus halus Salmonella memasuki Saluran limfatik dan kemudian masuk kealiran darah. Salmonella dibawa keberbagai organ oleh darah, salah satunya usus. Organisme tersebut memperbanyak diri di jaringan limfoid usus dan diekskresikan dalam feses.

Setelah periode inkubasi selama 10 - 14 hari, timbul demam, malaise, sakitkepala, konstipasi, bradikardia, dan myalgia. Demam mencapai plato yang tinggi, serta limpa dan hepar membesar. Meskipun jarang, rose spot dapat timbul sebentar, biasanya pada kulit perut atau dada. Hitung leukosit normal atau rendah. Pada masa sebelum ditemukannya antibiotik, komplikasi utama demam enteric adalah perdarahan dan perforasi usus, dan angka kematiannya mencapai $10-15 \%$. Terapi dengan antibiotic telah menurunkan angka kematian hingga kurang dari $1 \%$ (Jawetz, Melnick, \& Adelberg, 2010).

Penyakit typhus berdasarkan Riskesdas tahun 2007 secara nasional di Sulawesi Selatan, tersebar di semua umur dan cenderung lebih tinggi pada umur dewasa. Prevalensi klinis banyak ditemukan pada kelompok umur sekolah yaitu $1,9 \%$, terendah pada bayi yaitu $0,8 \%$.

Suspect penyakit typhus (demam typhoid) di Provinsi Sulawesi Selatan pada tahun 2014 sebanyak 23.271 yaitu laki-laki sebanyak 11.723 dan perempuan sebanyak 11. 548 sedangkan penderita demam typhoid sebanyak 16.743 penderita yaitu laki-laki sebanyak 7.925 dan perempuan sebanyak 8.818 penderita dengan insiden rate $(2,07)$ dan $(\mathrm{CFR}=0,00 \%)$, dengan kasus yang tertinggi yaitu di Kabupaten Bulukumba (3.270 kasus), Kota Makassar (2.325 kasus), Kabupaten Enrekang (1.153 kasus) dan terendah di Kabupaten Toraja (0 kasus), Kabupaten Luwu (1 kasus) dan Kabupaten Tana Toraja (19 kasus) (Depkes.go.id 2015).

Antibiotik merupakan senyawa yang dihasilkan dari mikroba terutama fungsi yang dapat digunakan untuk membunuh atau menekan pertumbuhan bakteri. Bakteri tersusun oleh komponen paling luar yaitu dinding sel yang mengandung peptidoglikan kecuali mycoplasma. Bagian lebih dalam dari dinding sel adalah membrane plasma, yang terdiri dari dua lapis fosfolipida dan protein. Dinding sel maupun membran plasma bakteri menjadi satu bagian membentuk struktur envelope, yang "membungkus" bakteri tersebut. Bagian lebih dalam dari membran plasma adalah sitoplasma, terdapat ribosom yang berperan dalam sintesis protein. Dalam sitoplasma tidak dijumpai inti sel maupun mitokondria. Oleh karena itu, DNA (kromosom) terdapat dalam sitoplasma tanpa adanya mitokondria, proses pembentukan energi berlangsung dalam membran plasma (Dr.AgungEndro).

Terapi anti mikroba untuk infeksi Salmonella invasif adalah dengan ampisilin, trimethoprimsulfametoksazol, Resistensi terhadap berbagai obat yang di transmisikan secara genetik melalui plasmid diantara bakteri enterik merupakan masalah pada infeksi Salmonella. Uji sensitivitas antibiotik merupakan pemeriksaan tambahan yang penting untuk memilih antibiotik yang sesuai (Jawetz DKK, 2010).

Penelitian yang dilakukan oleh Anggriana Alam (2011) didapatkan hasil 
dari 216 pasien demam tifoid. Selama tahun 2006-2010, S. typhi menunjukkan sensitivitas yang baik terhadap berbagai jenis antibiotik. Antibiotik lini pertama (kloramfenikol, ampisilin, dan trimetoprim-sulfametoksazol) $\quad 92-$ $100 \%$, seftriakson, sefotaksim, dan sefoperazon $95,7 \%-100 \%$, seftazidim $81,8 \%-100 \%$, meropenem $100 \%$, imipenem $94,7 \%-100 \%, \quad$ serta siprofloksasin $\quad 100 \% \quad$ sedangkan penelitian yang dilakukan oleh Jhons dan Jefri (2017) menunjukkan bahwa golongan penisilin yaitu amoksisilin dan gabungan amoksisilin-asam klavulanat memberikan sensitivitas terhadap Salmonella sp. yang masih tinggi 99,36$99,68 \%$.

\begin{tabular}{llr}
\multicolumn{3}{c}{ Berdasarkan uraian diatas peneliti } \\
ingin mengetahui sejauh mana \\
efektifnya beberapa antibiotik yang
\end{tabular} diberikan kepada penderita demam thypoid dengan metode pengujian mikrobiologis, yaitu uji sensitivitas. Uji sensitivitas itu sendiri adalah suatu teknik untuk menetapkan sensitivitas suatu antibiotika dengan mengukur efek senyawa tersebut pada pertumbuhan suatu mikroorganisme di Balai Besar Laboratorium Kesehatan Makassar.

\section{METODE}

Jenis penelitian ini adalah observasi laboratory tentang uji sensitivitas berbagai jenis antibiotik terhadap sampel penderita demam typhoid.

\section{Alat dan Bahan}

Alat yang digunakna yaitu vacutainer, alcohol swab, lampu spirtus, kapas lidi steril, rak pewarnaan, autoclave, incubator, ose bulat, ose jarum, bact alert, vitek 2 compact, blue tip, yellow tip, densicheck digital.

Bahan yang digunakan dalam peneltian ini adalah Salmonella Shigella atau Chromagar Salmonella, NaCL 0,45\% $\mathrm{pH} 5,0$, larutan pewarnaan gram.

\section{Populasi dan Sampel Penelitian}

Populasi dalam penelitian ini adalah salmonella sp yang di isolasi dari sampel penderita demam typhoid.

Sampel dalam penelitian ini adalah penderita demam typhoid yang hasil pemeriksaan widal pada $\mathrm{O}$ titernya $1 / 320$ yang berjumlah 30 sampel

\section{Prosedur Penelitian}

Identifikasi kuman salmonella pada penderita demam typhoid

a. Hari I

1. Darah $10 \mathrm{ml}$ di masukkan kedalam tabung bact alert.

2. Scan barcode pada botol

3. Masukan no accession

4. Masukan hospital ID

5. Masukan nama awa lpasien

6. Masukan nama akhir pasien

7. Masukan waktu inkubasi yang diperlukan

8. Masukan botol hanya pada drawer/rak yang lampunya menyala dan juga lihat cell yang lampunya menyala boleh dimana saja

9. Tekan tombol simpan data

b. Hari II

1. Jika hasil pada alat bact alert positif maka pada main screen akan berubah menjadi warna kuning hanya bila ada botol yang diidentifikasi positif sedangkan untuk botol yang negatif warna layar tidak berubah hanya warna tombol untuk mengeluarkan botol berubah menjadi biru (aktif). Pada main screen tekan tombol mengeluarkan botol. Kemudian tarik botolbact alert keluar dari drawer. Lalu tekan simpan data.

2. Dilakukan pewarnaan gram untuk mengetahui morfologi dari bakteri yang tumbuh pada botol bact alert. 
3. Setelah itu bakteri di tanam pada media SS dan inkubasi selama 24 jam dengan suhu $37^{\circ} \mathrm{C}$

c. Hari III

Koloni yang tumbuh pada media SS dilakukan pewarnaan gram untuk melihat morfologi bakteri yang tumbuh pada media SS. Selanjutnya dilakukan identifikasi bakteri dengan menggunakan alat vitek 2 compact.

\section{Analisis Data}

Data yang di dapatkan selanjutya dianalisis secara deskriptif dengan menampilkan hasil uji sensitifita smasing - masing antibiotik pada penderita demam typhoid.

\section{HASIL}

Demam Typhoid merupakan infeksi sistemik akut yang disebabkan oleh bakteri salmonella thypi. Infeksi sistemik akut ini yang menyebabkan bakteri salmonella thypi dapat masuk kedalam aliran darah setelah melalui beberapa organ yang terdapat dalam berbagai sistem di dalamm tubuh inang. Jumlah sampel darah 52 sampel dan dilakukan pengujian kultur darah dari penderita demam thypoid menggunakan Bact/Alert culture media. Setelah tumbuh pada media kultur Bact/Alert lalu dilakukan pengecatan gram untuk melihat morfologi bakteri yang tumbuh kemudian di tanam pada media SS. Setelah tumbuh pada media SS kemudian dilakukan pengecatan gram dan kemudian bakteri pada media SS diidentifikasi pada alat vitek 2 compact dan dilanjutkan dengan uji sensitifitas. Berdasarkan hasil uji sensitivitas dari 4 jenis antibiotik yang sensitif pada bakteri salmonella thypi adalah amoxicillin, ceftriaxone dan trimethoprim. Sedangkan antibiotik intermediate adalah ciprofloxacin.

Dari tabel dapat dilihat bahwa semua antibiotik uji telah ada yang resisten. Golongan amoxicillin memberikan hasil sensivitas yang masih tinggi yaitu $80,77 \%$ tapi ditemukan 9 sampel yang resisten $(17,31)$ dan 1 sampel yang intermediate $(1,92)$. Golongan antibiotik uji Ceftriaxone menunjukkan sensitivitas yang sangat tinggi, dari 52 sampel semua sampel sensitive (100\%). Pada golongan antibiotik uji Ciprofloxacin sudah tidak sensivitas, dari 52 sampel 12 sampel yang resisten $(23,07 \%)$ dan 40 sampel yang intermediate $(76,92 \%)$. Pada golongan antibiotic uji Trimethoprim menunjukkan sensitivitas yang sangat tinggi, dari 52 sampel yang sensitive 51 sampel $(98,08 \%)$ dan yang intermediate 1 sampel $(1,92)$. Dalam hal ini Ceftriaxone dan Trimethoprim sebagai drug of choice masih menunjukkan sensitivitas yang tinggi, yaitu $100 \%$ dan $98,08 \%$.

\section{PEMBAHASAN}

Hasil uji sensitifitas antibiotik yang dilakukan pada 4 sampel penderita demam typhoid dengan antibiotik amoxicillin, cetriaxone, ciprofloxacin dan trimethoprim. Antibiotik yang digunakan dalam penelitian ini terdiri dari 4 golongan yang berbeda.

1. Amoxicillin

Amoxicillin termasuk dalam golongan penisilin. Penisilin merupakan contok klasik obat golongan $\beta$-laktam yang mempunyai struktur kumia yang mengandung cincin $\beta$-laktam. Obat ini bersifat bakterisidal. Cincin $\beta$-laktam tersebut yang bertanggung jawab terhadap aktivitas antimikrobial. Pasa resistens terhadap bakteri yang mensekresi enzim $\beta$-laktamase ( Penisilase atauu Sefalosporinase ), yang dapat membuka cincin $\beta$-laktam mengakibatkan inaktivasi antimikrobial. 
Terjadinya resistensi nakteri diakibatkan terjadinya transfer plasmid kode genetik bagi enzim $\beta$ laktamase. Upaya antisipasi terhadap resistensi tersebut adalah pemberian penghambat enzim $\beta$-laktamase, contohnya asam klavulanat, sulbactam dan modifikasi gugus sehingga resisten terhadap enzim $\beta$ laktamase, contohnya amoxicillin, oksasilin.

Penisilin merupakan antibiotik pilihan pertama pada beberapa infeksi. Penisilin pertama kali ditemukan oleh alexander fleming pada tahun 1928 dari jamur golongan penicilium. Terdapat empat golongan senyawa penisilin, yaitu :

a. Penisilin alami, bersifat sensitif terhadap penisilinase dan berspektrum sempit hanya pada gram positif. Contohnya : Penisilin $\mathrm{G}$ dan penisilin $\mathrm{V}$.

b. Resisten terhadap penisilinase, produk sintesis yang resisten terhadap enzim $\beta$-laktamase, dan berspektrum sempit hanya pada bakteri gram positif. Contohnya : Methisilin, oksasilin, kloksasilin.

c. Aminopenisilin, bersifat sensitif terhadap penisilinase dan berspektrum lebih luas (Gram positif dan gram negatif). Contohnya : Amoxicillin dan ampisilin.

d. Turunan penisilin lain dengan spectrum diperluas. Golongan penisilin ini aktif terhadap pseudomonas dan klebsiella, namun tidak efektif terhadap bakteri gram positif. Contohnya : Mezlosilin dan piperasilin.

Penisilin mengalami ekskresi melalui proses sekresi tubular aktif. Penghambatan pada proses tersebut oleh probensid menyebabkan proses ekskresi penisilin terhambat sehingga kadarnya dalam darah lebih besar, dan penisilin menjadi lebih lama. Oleh karena itu, penisilin sering dikombinasikan dengan probenesid. Efek samping yang terpenting dari penisilin adalah reaksi hipersensitivitasi atau reaksi alergi, yang disebabkan oleh degradasi produk penisilin, yang berinteraksi dengan protein inang dan menjadi antigenic.

Dalam penilitian ini golongan penisilin yang digunakan adalah amoxicillin dimana golongan ini mempunyai mekanisme kerja menghambat sintesis peptidoglikan sehingga terjadi lisis osmotik. Pada uji sensitivitas amoxicillin sensitif terhadap bakteri salmonella thypi.

2. Cefriaxone

\begin{tabular}{ll}
\multicolumn{2}{c}{ Dalam penelitian ini } \\
golongan sefalosporin yang
\end{tabular}
digunakan adalah cefriaxone dimana golongan ini mempunyai mekanisme kerja mengikat protein bakteri, menghambat sintesis peptidoglikan dan enzim autolysin. Pada uji sensitifitas cetriaxone sensitif terhadap bakteri salmonella thypi.

Sefalosporin merupakan antibiotika pilihan kedua pada beberapa infeksi. Klasifikasi obat golongan ini berdasarkan generasi, yang pada dasarnya ditentukan oleh aktivitas antimikrobialnya.

a. Generasi pertama bersifat sensitif terhadap enzim $\beta$-laktamase, dan berspektrum sempit. Dalam hal ini, berspektrum sempit adalah relative, karena sebenarnya aksinya atau spectrum sefalosporin generasi pertama sama dengan penisilin dengan spectrum luas. Contoh dari generasi pertama adalah sefazolin dan sefaleksin.

b. Generasi kedua mempunyai stabilitas yang lebih baik, dan aktivitasnya terhadap bakteri gram 
negatif lebih tinggi. Contoh dari generasi kedua adalah sefaklor, sefamandol dan sefoksitin.

c. Generasi ketiga mempunyai sp[ektrum lebih luas dan lebih resisten terhadap enzim $\beta$ laktamase. Contoh dari generasi ketiga adalah sefotaksim, seftazidim dan setriakson. Obat generasi ini (dan sebagian generasi kedua) dapat menembus barner darah otak dan digunakan pada pengobatan meningitis.

d. Generasi keempat mempunyai aktivitas baik terhadap bakteri gram positif maupun gram negatif, dan mempunyai resistensi terhadap enzim $\beta$-laktamase yang lebih baik. Contoh dari generasi keempat adalah sefepim dan sefpirom.

e. Pada penelitian ini bakteri Salmonella $S p$ masih sensitive terhadap golongan penicilin. Dari 52 sampel penelitian sudah tampak adanya sampel yang resisten, hal ini perlu menjadi perhatian penggunaan antibiotik untuk terapi demam typhoid secara benar dan rasional agar tidak mempercepat resistensi.

f. Penelitian ini perlu dilakukan secara berkala untuk melihat ada atau tidak adanya peningkatan resistensi Salmonella sp. Terhadap antibiotik yang umumnya digunakan untuk demam typhoid.

g. Mengingat adanya kemungkinan Salmonella typhi dan Salmonella paratyphi resisten terhadap antibotik pilihan disarankan sebaiknya dilakukan tes resistensi terhadap Salmonella sp. pada penderita positif demam typhoid. Tes resistensi perlu dilakukan secara berkala dan terpadu untuk memantau peningkatan resistensi, karena penularan demam enterik ini dapat terjadi dengan mudah lewat makanan atau minuman yang terkontaminasi.

h. Pada pasien tertentu tidak tertutup kemungkinan pengobatannya dikombinasi dengan obat lain. Contohnya pada salah satu pasien ditemukan adanya tuberkulosis paru, oleh karena itu untuk pengobatannya diberikan tambahan antibiotik lain.

\section{Ciprofloxacin}

Dalam penilitian ini golongan kuinolon yang digunakan adalah ciprofloxacin dimana golongan ini mempunyai mekanisme kerja menghambat topoismerase yang bertanggung jawab pada pembuatan DNA bakteri dan menghambat DNA girase. Pada uji sensitifitas ciprofloxacin intermediate terhadap bekteri salmonella thypi.

4. Trimethoprim

Dalam penelitian ini golongan trimethoprim yang digunakan mempunyai mekanisme kerja menghambat asam dihidrofolat reduktase bakteri dan menghambat sintesis DNA. Pada uji sensitivitas trimethoprim sensitif terhadap bakteri salmonella thypi.

\section{KESIMPULAN}

Berdasarkan hasil penelitian maka uji sensitifitas terhadap salmonella sp yaitu pada antibiotik amoxicillin sensitif, antibiotik ceftriaxone sensitif, antibiotik ciprofloxacin intermediate, dan antibiotik trimethoprim sensitif.

\section{UCAPAN TERIMA KASIH}

Terimakasih diucapkan kepada Direktur dan civitas akademika Poltekkes Kemenkes Makassar yang telah memberikan bantuan dan dukungan untuk melakukan Tridarma 
Perguruan Tinggi khususnya dibidang penelitian.

\section{DAFTAR PUSTAKA}

Alam, A. 2011. Pola Resistensi Salmonella Enterica Serotipe Typhi. Departemen Ilmu Kesehatan Anak RSHS, Tahun 2006-2010, Sari Pediatri. Vo. 12 (5).

Amran, P. 2008. Analisis Keberadaan Gen H1-j Salmonella enterica serovar typhi Dengan Teknik Polymerase Chain Reaction (PCR) Dalam Darah Penderita Demam typhoid . (Thesis)

AyuPutri, 2017. Dasar-dasar Farmakologi,

PenerbitNuhaMedika: Yogyakarta Baratawidjaja, K.G \& Rengganis,I. 2009. Imunologi Dasar. Edisi VIII. Balai penerbit Fakultas Kedokteran Universitas Indonesia. Jakarta..

Darmawati. 2009. Keanekaragaman genetic Salmonella typhi. Analis kesehatan Fikkes UNIMUS. (jurnal kesehatan). Vol 2.No.1. Hal 27-33.

Garrity,G. 2000. Bergey's Manual of Systematic Bacteriology $2^{\text {nd }}$ Edittion.

Handjoeno, H. 2003. Interprestasi hasil tes laboratorium diagnostic bagian dari standard pelayanan medik. Lembaga penerbit Universitas Hasanuddin .Makassar. 21: 335-350.

Hatta, M \&Goris, M.G. 2002.Simple dipstick assay for the detection of salmonella typhi - Specific IgM antibodiesand the evolution of the immune response in patients with typhoid fever. Am J Trop Med Hyg66(4):416-21.

Hatta,M., Andi,S.R.,Pastoor, R and Smits,H.L. 2011. New flagellin gen forSalmonella enteric serovartyphi from the East Indonesia

Archipelago.Am.J.Trop.Med.Hyg. 00(0), pp000-000.

Irianto, Koes. 2006. Mikrobiologi :Menguak Dunia

Mikroorganisme. Jilid 2, Penerbit CV. Yrama Widya : Bandung

Jawetz.,Melnick\& Adelberg. 2008.Mikrobilogi Kedokteran. Edisi 23, Penerbit EGC :Jakarta.Hal 33-35, 131.

Jawetz., Melnick\& Adelberg. 2014.Mikrobilogi Kedokteran.

Edisi 25, Penerbit EGC :Jakarta

Kuswiyanto. 2016. Bakteriologi 1 Buku Ajar Analis Kesehatan, Penerbit EGC: Jakarta

Nelwan,R.H.H. 2012. Tata laksana terkini demam typhoid. CKD 192, Vol 39, No.4 Ok. Indd. Hal 247250.

Sunaryo, 2017. Kimia Farmasi. Penerbit EGC: Jakarta

Suwandi, J.F. dan Jefri. S. 2017. Sensitivitas Salmonella thypi Penyebab Demam typhoid terhadap Beberapa Antibiotik. Majority. Vol.6(1).

Syahrurachman, A., Karsinah., Lucky, H.M \&Mardiastuti, H.W. Buku Ajar Mikrobiologii Kedokteran. Penerbit Binarupa Aksara publisher 2010. Edisi Revisi. Fakultas Kedokteran Universitas Indonesia.

Widoyono, 2011. Penyakit Tropis Epidemiologi, Penularan

Pencegahan, \& Pembrantasannya, Semarang: Penerbit Erlangga: Jakarta

Yuwono, Triwibowo. 2006. Teori dan Aplikasi Polymerase Chain Reaction Panduan Eksperimen PCR untuk memecahkan Masalah Biolgi Terkini, Penerbit Andi. Yogyakarta. Hal 5-8, 17-25. 
Tabel 1. Hasil Identifikasi Bakteri Salmonella typhoid

\begin{tabular}{|c|c|c|}
\hline No & Pewarna Gram & Hasil Kultur Salmonella typhi \\
\hline 1 & Sampel 1 & Positif \\
\hline 2 & Sampel 2 & Positif \\
\hline 3 & Sampel 3 & Positif \\
\hline 4 & Sampel 4 & Positif \\
\hline 5 & Sampel 5 & Positif \\
\hline 6 & Sampel 6 & Positif \\
\hline 7 & Sampel 7 & Positif \\
\hline 8 & Sampel 8 & Positif \\
\hline 9 & Sampel 9 & Positif \\
\hline 10 & Sampel 10 & Positif \\
\hline 11 & Sampel 11 & Positif \\
\hline 12 & Sampel 12 & Positif \\
\hline 13 & Sampel 13 & Positif \\
\hline 14 & Sampel 14 & Positif \\
\hline 15 & Sampel 15 & Positif \\
\hline 16 & Sampel 16 & Positif \\
\hline 17 & Sampel 17 & Positif \\
\hline 18 & Sampel 18 & Positif \\
\hline 19 & Sampel 19 & Positif \\
\hline 20 & Sampel 20 & Positif \\
\hline 21 & Sampel 21 & Positif \\
\hline 22 & Sampel 22 & Positif \\
\hline 23 & Sampel 23 & Positif \\
\hline 24 & Sampel 24 & Positif \\
\hline 25 & Sampel 25 & Positif \\
\hline 26 & Sampel 26 & Positif \\
\hline 27 & Sampel 27 & Positif \\
\hline 28 & Sampel 28 & Positif \\
\hline 29 & Sampel 29 & Positif \\
\hline 30 & Sampel 30 & Positif \\
\hline 31 & Sampel 31 & Positif \\
\hline 32 & Sampel 32 & Positif \\
\hline 33 & Sampel 33 & Positif \\
\hline 34 & Sampel 34 & Positif \\
\hline 35 & Sampel 35 & Positif \\
\hline 36 & Sampel 36 & Positif \\
\hline 37 & Sampel 37 & Positif \\
\hline 38 & Sampel 38 & Positif \\
\hline 39 & Sampel 39 & Positif \\
\hline 40 & Sampel 40 & Positif \\
\hline 41 & Sampel 41 & Positif \\
\hline 42 & Sampel 42 & Positif \\
\hline
\end{tabular}




\begin{tabular}{lll}
\hline 43 & Sampel 43 & Positif \\
\hline 44 & Sampel 44 & Positif \\
\hline 45 & Sampel 45 & Positif \\
\hline 46 & Sampel 46 & Positif \\
\hline 47 & Sampel 47 & Positif \\
\hline 48 & Sampel 48 & Positif \\
\hline 49 & Sampel 49 & Positif \\
\hline 50 & Sampel 50 & Positif \\
\hline 51 & Sampel 51 & Positif \\
\hline 52 & Sampel 52 & Positif \\
\hline
\end{tabular}

Tabel 2. Hasil Uji Sensitifitas

\begin{tabular}{|c|c|c|c|c|c|}
\hline No & $\begin{array}{c}\text { Kode } \\
\text { Sampel }\end{array}$ & Amoxicillin & Cefriaxone & Ciprofloxacin & Trimethoprim \\
\hline 1 & Sampel 1 & $\mathrm{~S}$ & $\mathrm{~S}$ & I & S \\
\hline 2 & Sampel 2 & $\mathrm{R}$ & $S$ & $\mathrm{R}$ & $\mathrm{S}$ \\
\hline 3 & Sampel 3 & $S$ & $S$ & I & $\mathrm{S}$ \\
\hline 4 & Sampel 4 & $\mathrm{R}$ & S & I & S \\
\hline 5 & Sampel 5 & $S$ & $\mathrm{~S}$ & I & I \\
\hline 6 & Sampel 6 & $S$ & $S$ & I & $S$ \\
\hline 7 & Sampel 7 & $\mathrm{R}$ & $S$ & $\mathrm{R}$ & $S$ \\
\hline 8 & Sampel 8 & $S$ & S & I & $\mathrm{S}$ \\
\hline 9 & Sampel 9 & $\mathrm{R}$ & $S$ & $\mathrm{R}$ & $S$ \\
\hline 10 & Sampel 10 & $S$ & $S$ & $\mathrm{R}$ & $S$ \\
\hline 11 & Sampel 11 & $\mathrm{~S}$ & $\mathrm{~S}$ & I & $\mathrm{S}$ \\
\hline 12 & Sampel 12 & $S$ & $S$ & I & $S$ \\
\hline 13 & Sampel 13 & $S$ & $S$ & I & $S$ \\
\hline 14 & Sampel 14 & $\mathrm{R}$ & $S$ & I & $S$ \\
\hline 15 & Sampel 15 & $S$ & $S$ & I & $S$ \\
\hline 16 & Sampel 16 & $\mathrm{R}$ & $S$ & I & $\mathrm{S}$ \\
\hline 17 & Sampel 17 & $S$ & $S$ & I & $S$ \\
\hline 18 & Sampel 18 & $S$ & $S$ & I & S \\
\hline 19 & Sampel 19 & $S$ & $S$ & I & $S$ \\
\hline 20 & Sampel 20 & $S$ & $S$ & I & S \\
\hline 21 & Sampel 21 & S & S & I & S \\
\hline 22 & Sampel 22 & $S$ & $S$ & $\mathrm{R}$ & $S$ \\
\hline 23 & Sampel 23 & $S$ & $S$ & I & $S$ \\
\hline 24 & Sampel 24 & $S$ & $S$ & I & $S$ \\
\hline 25 & Sampel 5 & $S$ & S & $\mathrm{R}$ & S \\
\hline 26 & Sampel 26 & $S$ & S & $\mathrm{R}$ & S \\
\hline 27 & Sampel 27 & $S$ & $S$ & I & S \\
\hline 28 & Sampel 28 & $S$ & $S$ & I & $S$ \\
\hline 29 & Sampel 29 & $S$ & $S$ & $\mathrm{I}$ & $S$ \\
\hline 30 & Sampel 30 & S & S & I & S \\
\hline 31 & Sampel 31 & $S$ & $\mathrm{~S}$ & I & S \\
\hline
\end{tabular}




\begin{tabular}{|c|c|c|c|c|c|}
\hline 32 & Sampel 32 & $S$ & $S$ & $\mathrm{R}$ & $S$ \\
\hline 33 & Sampel 33 & S & S & I & S \\
\hline 34 & Sampel 34 & I & S & I & S \\
\hline 35 & Sampel 35 & $S$ & $S$ & I & $S$ \\
\hline 36 & Sampel 36 & $S$ & $S$ & I & $S$ \\
\hline 37 & Sampel 37 & $S$ & $S$ & $\mathrm{R}$ & $S$ \\
\hline 38 & Sampel 38 & S & S & I & S \\
\hline 39 & Sampel 39 & $S$ & $S$ & $\mathrm{I}$ & $S$ \\
\hline 40 & Sampel 40 & S & S & I & S \\
\hline 41 & Sampel 41 & $S$ & $S$ & I & $S$ \\
\hline 42 & Sampel 42 & $S$ & $S$ & $\mathrm{R}$ & $\mathrm{S}$ \\
\hline 43 & Sampel 43 & $S$ & $S$ & I & $S$ \\
\hline 44 & Sampel 44 & $\mathrm{R}$ & $S$ & I & $\mathrm{S}$ \\
\hline 45 & Sampel 45 & $S$ & $S$ & I & $S$ \\
\hline 46 & Sampel 46 & S & S & I & $S$ \\
\hline 47 & Sampel 47 & $S$ & $S$ & I & $S$ \\
\hline 48 & Sampel 48 & $S$ & $S$ & $\mathrm{R}$ & $\mathrm{S}$ \\
\hline 49 & Sampel 49 & $S$ & $S$ & I & $S$ \\
\hline 50 & Sampel 50 & $\mathrm{R}$ & $S$ & $\mathrm{R}$ & $S$ \\
\hline 51 & Sampel 51 & $\mathrm{R}$ & $S$ & I & $S$ \\
\hline 52 & Sampel 52 & S & S & I & $S$ \\
\hline
\end{tabular}

Keterangan : S : Sensitive, I :

Intermediate, $\mathrm{R}:$ Resisten

Tabel 3 Tes Sensitivitas dari 52 Sampel Uji Sensitivitas Berbagai Jenis Antibiotik Terhadap Salmonella sp yang Diisolasi dari Penderita Demam Typhoid

\begin{tabular}{lcccccc}
\hline Antibiotik uji & Sensitive & \% & Resistant & \% & Intermediate & \% \\
\hline \hline Amoxicillin & 42 & 80,77 & 9 & 17,31 & 1 & 1,92 \\
Ceftriaxone & 52 & 100 & - & - & - & - \\
Ciprofloxacin & - & - & 12 & 23,07 & 40 & 76,92 \\
Trimethoprim & 51 & 98,08 & - & - & 1 & 1,92 \\
\hline
\end{tabular}

